\title{
Comparison of Probiotic Lactobacillus acidophilus and Oxytetracycline for the Treatment of Early Stage Interdigital Necrobacillosis in Dairy Cows
}

\author{
Zhanara Kenesovna Tulemissova ${ }^{1}$, Merej Ajbynovich Torehanov ${ }^{1}$, Raya Zhaksygulovna Myktybayeva ${ }^{2}$, Assem \\ Serikovna Ibazhanova ${ }^{1 *}$, Damir Mikdatovich Khussainov ${ }^{1}$, Zhanat Mukhametkaliyevna Batanova ${ }^{1}$, and Symbat \\ Suttibayevna Usmangaliyeva ${ }^{1}$
}

${ }^{I}$ Department of Biological Safety, Kazakh National Agrarian University, 050000 Almaty, Kazakhstan

${ }^{2}$ Department of Microbiology and Virology, Kazakh National Agrarian University, 050000 Almaty, Kazakhstan

*Corresponding author's Email: assemibazhanova@yahoo.com; (DORCiD: 0000-0002-2833-1413

\begin{abstract}
The objective of this multilocation field trial was to compare the effectiveness of the topical application of a powdered probiotic strain and intramuscular injection of oxytetracycline for the treatment of interdigital necrobacillosis in dairy cows. The current study was conducted from April 2018 to May 2020 on 230 dairy cows with early-stage interdigital necrobacillosis diagnosed by the research veterinarians on 6 farms situated in the Almaty region of Kazakhstan. The animals were recruited randomly to one of the following groups. A trial group in which the affected hoof of a cow was cleaned, coated with powder containing $10^{6}$ colony-forming units of Lactobacillus acidophilus per gram, and then bandaged. Cows in the positive control group were subjected to a single intramuscular injection of oxytetracycline at the dosage of 1.0 milligram per kilogram of bodyweight which is considered the routine treatment for interdigital necrobacillosis in the feedlots. Both procedures were executed every 72 hours during a period of two weeks with the subsequent two-week follow-up period. The treatment was discontinued when a cow was assessed as cured. Both groups were monitored daily for their limb condition and the degree of lameness during 28 days. Those cows having no evidence of lameness and lesions attributed to interdigital necrobacillosis with no disease recurrence recorded within the observation period, were considered cured. On day 15, the overall cure rates for Lactobacillus acidophilus $015 \mathrm{k}-1$ strain and oxytetracycline were $80.87 \%$ and $83.48 \%$, respectively. The overall odds ratio for the cure rate in the probiotic group versus oxytetracycline was 0.837 . However, on day 28, all cows in both groups were found to be clinically free from the disease, and cure rates were $100 \%$. No recurrence was recorded in any of the cases. It was concluded that the topical administration of the probiotic powder to dairy cows with early-stage interdigital necrobacillosis can result in cure rates nearly as high as those for intramuscular oxytetracycline within a period of 28 days. This is the first report on the treatment effect of Lactobacillus acidophilus locally applied to cattle with early-stage interdigital necrobacillosis.
\end{abstract}

Keywords: Dairy cows, Foot rot, Interdigital necrobacillosis, Lactobacillus acidophilus, Oxytetracycline, Probiotic, Topical administration

\section{INTRODUCTION}

Interdigital necrobacillosis (IN) is an infectious podal disease caused mainly by Fusobacterium necrophorum and Dichelobacter nodosus. These Gram-negative aerotolerant anaerobic bacteria symbiotically produce several toxins and extracellular enzymes involved in the degradation of immunologically competent cells of host, bacterial proliferation, and dermotoxic activity (Nagaraja, 2016; Osová et al., 2018; Carvallo et al., 2020). D. nodosus inhabits the epidermis covering the limbs of cattle, whereas $F$. necrophorum is normally present in the digestive tract of healthy cattle, but once penetrated into other tissues, it can turn into a necrosis-inducing opportunistic pathogen (Francis et al., 2019). The common clinical signs of IN include lameness (most frequently unilateral), fever, reduced feed intake, edema, and erythema in the interdigital space and the coronary band (Van Metre, 2017).

Despite the array of steps towards effective treatments for IN the disease is still distributed in many countries (Renault et al., 2018; Dendani-Chadi et al., 2020; Silva et al., 2020). In the past few decades, the efficacy of vaccination against IN has been called into question on account of a number of issues, such as serogroup conversion of the infectious agents or diet-dependent effect (Checkley et al., 2005; Markey et al., 2013). A recent study on sheep with footrot has disclosed that a whole-cell D. nodosus vaccine and a recombinant fimbrial vaccine could reduce the disease with approximately twice less efficaciousness as opposed to foot bathing regimens (Allworth and Egerton, 2018).

Regarding probiotics, the experimental evidence demonstrates the capability of different Lactobacillus acidophilus strains to suppress Listeria, Shigella, Salmonella Typhimurium, Escherichia coli, and other pathogens through a variety 
of mechanisms, such as membrane depolarization and intracellular acidification (Liévin-Le Moal and Servin, 2014). An in vitro study has also revealed the antagonistic activity of L. acidophilus $015 \mathrm{k}-1$ strain against F. necrophorum strains isolated from limbs of cattle (Myktybaeva et al., 2020).

Therefore, the purpose of this multilocation field trial was to compare the effectiveness of the topical application of a powdered L. acidophilus $015 \mathrm{k}-1$ strain and intramuscular injection of oxytetracycline for the treatment of IN in dairy cows.

\section{MATERIALS AND METHODS}

\section{Ethical approval}

All procedures involving the cattle were performed in conformity with Directive 2010/63/EU and were approved by the ethics committee of Kazakh National Agrarian University (Almaty, Kazakhstan).

\section{Study design}

This research was conducted on six farms with a total of 1291 cows, located in the Almaty region of Kazakhstan from April 2018 to May 2020. Cattle were housed in open dirt feedlot pens. In each case, research veterinarians performed clinical examination of the cattle. Cows exhibiting early signs of IN represented by lesions graded as 1 or 2 in accordance with a standard scoring system (Jelinek et al., 2001) and a mild degree of lameness according to Jaeger (2016), were allocated randomly to one of two groups. The trial group consisted of cows for which the affected hoof was cleaned, coated with probiotic powder (Lactobacterin-TK2®, Akyntaj LLP, Kazakhstan) containing $10^{6}$ colony-forming units of L. acidophilus 015k-1 per gram, and then bandaged (Figure 1). On the other hand, cows in the control group were subjected to a single intramuscular injection of Nitox 200® (oxytetracycline; Nita-farm, Russia) at the dosage of 1.0 milligram per kilogram of bodyweight which is considered the routine treatment for IN in the feedlots. Both procedures were performed every 72 hours during a period of two weeks with the subsequent two-week follow-up period. In case a cow was assessed as cured during this period, its treatment was discontinued. Each cow was ear-tagged. Both groups were monitored daily by licensed veterinarians for the condition of the limb and the degree of lameness during 28 days. Those cows having no evidence of lameness and lesions attributed to IN, with no disease recurrence recorded within the observation period, were considered cured.

\section{Statistical analysis}

In order to evaluate the association between variables, two-sided Fisher's exact test was used in the current study. For each of the herds pulled, the odds ratios of clinical cure of cows treated with L. acidophilus $015 \mathrm{k}-1$ versus oxytetracycline were computed along with the confidence interval estimated by the Baptista-Pike method. All calculations were carried out in GraphPad Prism version 8.3.0 for Windows (GraphPad Software, San Diego, California, USA).

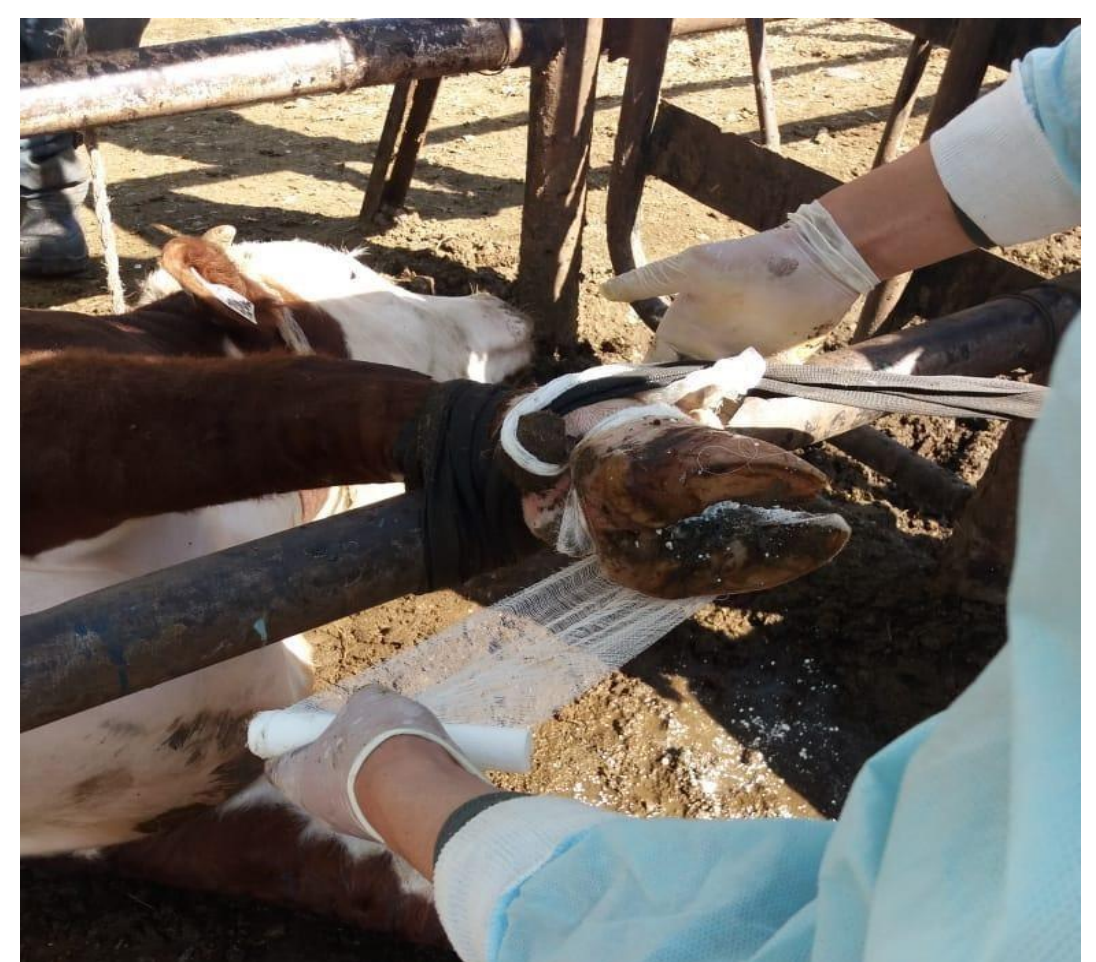

Figure 1. The procedure of applying Lactobacillus acidophilus $015 \mathrm{k}-1$ to the foot of a cow with interdigital necrobacillosis 
Among the animals examined, 230 of them were diagnosed with early-stage IN (Table 1).

Cure rates for both treated groups on day 15 of treatment are shown in Table 2.

On day 15 , the overall cure rates for L. acidophilus $015 \mathrm{k}-1$ and oxytetracycline were $80.87 \%$ and $83.48 \%$, respectively. The overall odds ratio for the cure rate in the L. acidophilus group versus oxytetracycline was 0.837 . This means that the odds of cure after two weeks of the topical application of L. acidophilus are $83.7 \%$ of the odds of cure after a two-week-long intramuscular injection of oxytetracycline (Ranganathan et al., 2015). However, on day 28, all cows in both groups were found to be clinically free from IN, and consequently, the cure rates were $100 \%$. For this reason, the data are not displayed in a tabular form. There was no recurrence of IN during the observation period.

Table 1. Prevalence of early-stage interdigital necrobacillosis in dairy cows included in the study on livestock farms located in the Almaty region of Kazakhstan

\begin{tabular}{llccc}
\hline Farm name & Trial period & $\begin{array}{c}\text { Cows } \\
\text { (total) }\end{array}$ & $\begin{array}{c}\text { Cows with early-stage IN (included in } \\
\text { probiotic-treated group }{ }^{\mathbf{1}} \text { ) }\end{array}$ & $\begin{array}{c}\text { Cows with early-stage IN (included } \\
\text { in antibiotic-treated group } \mathbf{2}^{\mathbf{2}} \text { ) }\end{array}$ \\
\hline Darnis & April - May 2018 & 262 & 19 & 19 \\
\hline Bajserke - Agro & September - October 2018 & 536 & 27 & 27 \\
\hline Almaty & March - April 2019 & 118 & 16 & 13 \\
\hline Anar - K & May 2019 & 68 & 12 & 13 \\
\hline Nurzhan & September - October 2019 & 75 & 28 & 12 \\
\hline Samsybaev M & April - May 2020 & 232 & 115 & 28 \\
\hline Total & April 2018 - May 2020 & 1291 & 115 \\
\hline
\end{tabular}

IN: interdigital necrobacillosis ${ }^{1}$ topical administration of probiotic powder containing $10^{6}$ colony-forming units of Lactobacillus acidophilus $015 \mathrm{k}-1$ per gram. ${ }^{2}$ single intramuscular injection of oxytetracycline at the dosage of $1 \mathrm{mg} / \mathrm{kg}$ of body weight.

Table 2. Cure rates for early-stage interdigital necrobacillosis in dairy cows included in the study on livestock farms located in the Almaty region of Kazakhstan on day 15 of treatment

\begin{tabular}{|c|c|c|c|c|c|c|c|}
\hline \multirow{3}{*}{ Farm name } & \multirow{2}{*}{\multicolumn{2}{|c|}{$\begin{array}{c}\text { Probiotic-treated group }^{1} \\
\text { cured / treated }\end{array}$}} & \multirow{2}{*}{\multicolumn{2}{|c|}{$\begin{array}{c}\text { Antibiotic-treated group }^{2} \\
\text { cured / treated }\end{array}$}} & \multirow{3}{*}{$\begin{array}{c}P \text {-value } \\
\text { (Fisher's } \\
\text { exact test) }\end{array}$} & \multirow{3}{*}{ OR } & \multirow{3}{*}{ CI } \\
\hline & & & & & & & \\
\hline & number & $\%$ & number & $\%$ & & & \\
\hline Darnis & $12 / 19$ & 63.16 & $16 / 19$ & 84.21 & 0.269 & 0.321 & $0.080-1.339$ \\
\hline Bajserke - Agro & $25 / 27$ & 92.59 & $21 / 27$ & 77.78 & 0.250 & 3.571 & $0.746-18.430$ \\
\hline Almaty & $9 / 16$ & 56.25 & $14 / 16$ & 87.50 & 0.113 & 0.184 & $0.035-1.000$ \\
\hline Anar - K & $10 / 13$ & 76.92 & $13 / 13$ & 100.00 & 0.220 & 0.000 & $0.000-1.065$ \\
\hline Nurzhan & $10 / 12$ & 83.33 & $8 / 12$ & 66.67 & 0.640 & 2.500 & $0.410-15.180$ \\
\hline Samsybaev M & $27 / 28$ & 96.43 & $24 / 28$ & 85.71 & 0.352 & 4.500 & $0.644-56.790$ \\
\hline Total & $93 / 115$ & 80.87 & $96 / 115$ & 83.48 & 0.731 & 0.837 & $0.423-1.616$ \\
\hline
\end{tabular}

OR: Odds ratio, CI: Confidence interval ${ }^{1}$ topical administration of probiotic powder containing $10^{6}$ colony-forming units of Lactobacillus acidophilus $015 \mathrm{k}-1$ per gram. ${ }^{2}$ single intramuscular injection of oxytetracycline at the dosage of $1 \mathrm{mg} / \mathrm{kg}$ of body weight. Treatments were repeated every 72 hours for two weeks but when a cow was assessed as cured, treatment was discontinued.

\section{DISCUSSION}

Considering that the initial point of foot rot is cutaneous dysbiosis, Ross et al. (2019) hypothesized that a probiotic culture with experimentally established efficacy against skin diseases might be a feasible topical treatment option. In line with the above, L. acidophilus has been widely proven to modulate epidermal conditions positively by means of cellular metabolites, antimicrobial peptides, and immune responses (Jeong et al., 2016; Lim et al., 2020). In contrast with antibiotics, the utilization of L. acidophilus $015 \mathrm{k}-1$ does not entail the risk of antimicrobial resistance, and it requires no painful injections.

Unfortunately, we have failed to find a published study designed to evaluate the effect of any topical probiotic on foot lesions in livestock. In general, there has been a dearth of research addressing the topical application of a nonantibiotic approach for IN eradication. In a study conducted by Kaler et al. (2012), it was found that at the end of their 28-day-long trial the recovery from the disease was observed in only four out of the ten sheep with at least moderate interdigital phlegmon that had been administered locally with potassium permanganate solution, whilst recovery in a median time of 7 days was recorded for those 52 sheep treated with long-acting parenteral oxytetracycline and enrofloxacin.

Furthermore, Van Metre (2017) in his narrative review, has drawn a skeptical conclusion about the full range of 
transdermal substances utilized as active agents against claw disorders. Nonetheless, Persson et al. (2019) stated that dairy cows with early detected foot rot which were subjected to $100 \%$ salicylic acid powder into the interdigital space of the feet showed improvement in their general condition, lameness, body temperature, and coronary circumference after five days since administration. Given the difference in the duration of these trials, it is not possible to compare these findings with the obtained results of the current research.

To the best knowledge of the authors, the current study is the first report on the treatment effect of L. acidophilus topically administered to cattle with early-stage IN. The limitation of this research is in the absence of laboratory diagnosis. Meanwhile, it should be noted that the diagnosis of IN on grounds of clinical signs is used in contemporary veterinary practice for a variety of reasons (Osová et al., 2017; Põder, 2018; Kontturi, et al., 2020).

\section{CONCLUSION}

In conclusion, it can be stated that the cutaneous administration of L. acidophilus $015 \mathrm{k}-1$ to dairy cows with early-stage IN every 72 hours for a period of up to two weeks can result in cure rates nearly as high as those for oxytetracycline intramuscularly injected using the same scheme. In the present case, the full recovery from the disease could be observed in both treatments at the end of the subsequent two-week follow-up period.

\section{DECLARATIONS}

\section{Authors' contribution}

All authors contributed equally to this work.

\section{Competing interests}

The authors declared no conflict of interest.

\section{Acknowledgments}

Authors wish to express their thanks to Sergey Sergeevich Kozhevnikov for translating this manuscript into the English language.

\section{REFERENCES}

Allworth MB and Egerton JR (2018). Comparison of footbathing and vaccination to control ovine footrot in an experimentally infected flock. Australian Veterinary Journal, 96(10): 395-399. DOI: http://dx.doi.org/10.1111/avj.12715

Carvallo FR, Uzal FA, Flores C, Diab SS, Giannitti F, Crossley B and Wünschmann A (2020). Alimentary necrobacillosis in alpacas. Journal of Veterinary Diagnostic Investigation, 32(2): 339-343. DOI: https://doi.org/10.1177/1040638720906409

Checkley SL, Janzen ED, Campbell JR and McKinnon JJ (2005). Efficacy of vaccination against Fusobacterium necrophorum infection for control of liver abscesses and footrot in feedlot cattle in western Canada. Canadian Veterinary Journal, 46(11): 1002-1007. Available at: https://pubmed.ncbi.nlm.nih.gov/16363327/

Dendani-Chadi Z, Saidani K, Dib L, Zeroual F, Sammar F and Benakhla A (2020). Univariate associations between housing, management, and facility design factors and the prevalence of lameness lesions in fourteen small-scale dairy farms in Northeastern Algeria. Veterinary World, 13(3): 570. DOI: www.doi.org/10.14202/vetworld.2020.570-578

Francis AM, Jeon SJ, Cunha F, Jeong KC and Galvão KN (2019). Draft genome sequences of two Fusobacterium necrophorum Strains Isolated from the Uterus of Dairy Cows with Metritis. Microbiology Resource Announcements, 8(17): e00201-19. DOI: https://doi.org/10.1128/MRA.00201-19

Jaeger M (2016). Trait Atlas: Guidelines for standardized measurements of fertility-, health- and milk records, Available at: https://orgprints.org/30824/1/Guide_ohne_bilder.pdf

Jelinek PD, Depiazzi LJ, Galvin DA, Spicer IT, Palmer MA and Pitman DR (2001). Eradication of ovine footrot by repeated daily footbathing in a solution of zinc sulphate with surfactant. Australian Veterinary Journal, 79(6): 431-434. DOI: https://doi.org/10.1111/j.1751-0813.2001.tb12991.x

Jeong JH, Lee CY and Chung DK (2016). Probiotic lactic acid bacteria and skin health. Critical Reviews in Food Science and Nutrition, 56(14): 2331-2337. DOI: https://doi.org/10.1080/10408398.2013.834874

Kaler J, Wani SA, Hussain I, Beg SA, Makhdoomi M, Kabli ZA and Green LE (2012). A clinical trial comparing parenteral oxytetracyline and enrofloxacin on time to recovery in sheep lame with acute or chronic footrot in Kashmir, India. BMC Veterinary Research, 8(1): 12. DOI: https://doi.org/10.1186/1746-6148-8-12

Kontturi M, Junni R, Kujala-Wirth M, Malinen E, Seuna E, Pelkonen S, Soveri T and Simojoki H (2020). Acute phase response and clinical manifestation in outbreaks of interdigital phlegmon in dairy herds. Comparative Immunology, Microbiology and Infectious Diseases, 68: 101375. DOI: https://doi.org/10.1016/j.cimid.2019.101375

Liévin-Le Moal V and Servin AL (2014). Anti-infective activities of Lactobacillus strains in the human intestinal microbiota: from probiotics to gastrointestinal anti-infectious biotherapeutic agents. Clinical Microbiology Reviews, 27(2): 167-199. DOI: https://doi.org/10.1128/CMR.00080-13

Lim HY, Jeong D, Park SH, Shin KK, Hong YH, Kim E, Yu YG, Kim TR, Kim H, Lee J and Cho JY (2020). Antiwrinkle and 
antimelanogenesis effects of tyndallized Lactobacillus acidophilus KCCM12625P. International Journal of Molecular Sciences, 21(5): 1620. DOI: https://doi.org/10.3390/ijms21051620

Markey B, Leonard F, Archambault M, Cullinane A and Maguire D (2013). Clinical Veterinary Microbiology. Elsevier Health Sciences, Edinburgh, p. 205.

Myktybaeva RZh, Tulemisova ZhK, Kozhahmetova ZA and Aknazarov BK (2020). Effektivnost' molochnokislyh bakterij pri nekrobakterioze krupnogo rogatogo skota. Vestnik Kyrgyzskogo Nacional'nogo Agrarnogo Universiteta im. KI Skryabina, 52(1): 46-50 (In Russian). Available at: https://www.elibrary.ru/item.asp?id=42905246

Nagaraja TG (2016). Ruminal microbes, microbial products, and systemic inflammation. Journal of Animal Science, 94 (supplement 5): 90. DOI: https://doi.org/10.2527/jam2016-0186

Osová A, Mihajlovičová X, Hund A and Mudroň P (2017). Interdigital phlegmon (foot rot) in dairy cattle - an update. Wiener Tierärztliche Monatsschrift, 104(7-8): 209-220. Available at: https://www.researchgate.net/publication/321098432_Interdigital_phlegmon_foot_rot_in_dairy_cattle_-_an_update

Osová A, Pilipčincová ISB, Király J, Dolník M and Mudroň P (2018). Assessment of two different methods for sampling and detection of Dichelobacter nodosus and Fusobacterium necrophorum in dairy cows in Eastern Slovakia. Journal of Applied Animal Research, 46(1): 1452-1456. DOI: https://doi.org/10.1080/09712119.2018.1532903

Persson Y, Jansson Mörk M, Pringle M and Bergsten C (2019). A case-series report on the use of a salicylic acid bandage as a nonantibiotic treatment for early detected, non-complicated interdigital phlegmon in dairy cows. Animals, 9(4): 129. DOI: https://doi.org/10.3390/ani9040129

Põder AK (2018). Meat inspection findings indicating necrobacillosis in Finnish reindeer during 2004-2016. Master's thesis, Eesti Maaülikool, Tartu, $\quad$ Estonia. $\quad$ p. $\quad 10 . \quad$ Available at: http://dspace.emu.ee/xmlui/bitstream/handle/10492/4223/Aino_Poder_MA2018.pdf?sequence=1

Ranganathan P, Aggarwal R and Pramesh CS (2015). Common pitfalls in statistical analysis: odds versus risk. Perspectives in Clinical Research, 6(4): 222-224. DOI: https://doi.org/10.4103/2229-3485.167092

Renault V, Damiaans B, Sarrazin S, Humblet MF, Lomba M, Ribbens S, Riocreux F, Koenen F, Cassart D, Dewulf J, Saegerman C et al. (2018). Classification of adult cattle infectious diseases: A first step towards prioritization of biosecurity measures. Transboundary and Emerging Diseases, 65(6): 1991-2005. DOI: https://doi.org/10.1111/tbed.12982

Ross AA, Hoffmann AR and Neufeld JD (2019). The skin microbiome of vertebrates. Microbiome, 7(1): 1-14. DOI: https://doi.org/10.1186/s40168-019-0694-6

Silva DC, Queiroz PJB, Borges PAC, da Rosa Pedroso ACB, Arnhold E, da Cruz AS, da Cruz AD and da Silva LAF (2020). Half a century of research on cattle foot and claw diseases: a scientometric analysis. Semina: Ciências Agrárias, 41(1): 223-236. Available at: http://www.uel.br/revistas/uel/index.php/semagrarias/article/view/36340

Van Metre DC (2017). Pathogenesis and treatment of bovine foot rot. Veterinary Clinics: Food Animal Practice, 33(2): 183-194. DOI: https://doi.org/10.1016/j.cvfa.2017.02.003 